\title{
Batson's plexus and retrograde venous spread of malignancy - a pictorial review
}

\author{
RC Brook ${ }^{*}$ K Tung, R Oeppen \\ From International Cancer Imaging Society (ICIS) 14th Annual Teaching Course \\ Heidelberg, Germany. 9-11 October 2014
}

\begin{abstract}
Aim
Batson's venous plexus is a system of paravertebral veins that connect pelvic and thoracic vessels to the intraspinal (basivertebral) veins. It was first described in 1940 to explain a route for spread of metastases and infection that was separate to the lymphatic system. Its role in the retrograde venous spread of malignancy is now well-described, but not widely demonstrated on imaging.
\end{abstract}

\section{Method \& results}

We present a detailed pictorial review of imaging of patients from our oncology centre showing retrograde venous spread to the paravertebral vessels specifically in cases of renal, rectal and breast carcinoma.

We demonstrate expansion of the paravertebral vessels containing tumour and associated vertebral body metastases.

We also review and illustrate the spinal venous anatomy.

\section{Conclusion}

Radiologists should be aware of the implication of Batson's venous plexus as a route of metastatic dissemination. Our pictorial review highlights the importance of the paravertebral vessels as a review area.

Submit your next manuscript to BioMed Central and take full advantage of:

- Convenient online submission

- Thorough peer review

- No space constraints or color figure charges

- Immediate publication on acceptance

- Inclusion in PubMed, CAS, Scopus and Google Scholar

- Research which is freely available for redistribution

Submit your manuscript at www.biomedcentral.com/submit
() Biomed Central

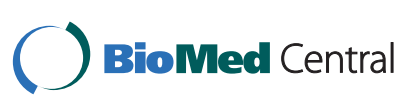

